\title{
Water-Energy-Nutrients Synergies in the Agrifood Sector: A Circular Economy Framework
}

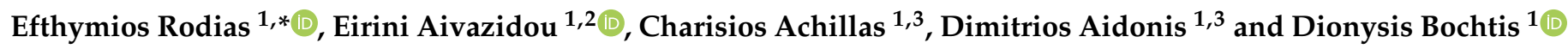 \\ 1 Institute for Bio-Economy and Agri-Technology (iBO), Centre for Research and Technology-Hellas (CERTH), \\ 10th km Charilaou-Thermi Road, Balkan Centre, 57001 Thermi, Greece; e.aivazidou@certh.gr (E.A.); \\ c.achillas@ihu.edu.gr (C.A.); daidonis@ihu.gr (D.A.); d.bochtis@certh.gr (D.B.) \\ 2 Department of Industrial Management, School of Mechanical Engineering, Aristotle University of \\ Thessaloniki, P.O. Box 461, 54124 Thessaloniki, Greece \\ 3 Department of Supply Chain Management, School of Economics and Business Administration, International \\ Hellenic University, 60100 Katerini, Greece \\ * Correspondence: e.rodias@certh.gr
}

check for updates

Citation: Rodias, E.; Aivazidou, E.; Achillas, C.; Aidonis, D.; Bochtis, D. Water-Energy-Nutrients Synergies in the Agrifood Sector: A Circular Economy Framework. Energies 2021, 14,159 .

https:/ / doi.org/10.3390/en14010159

Received: 1 December 2020

Accepted: 25 December 2020

Published: 30 December 2020

Publisher's Note: MDPI stays neutral with regard to jurisdictional clai$\mathrm{ms}$ in published maps and institutional affiliations.

Copyright: (C) 2020 by the authors. Licensee MDPI, Basel, Switzerland. This article is an open access article distributed under the terms and conditions of the Creative Commons Attribution (CC BY) license (https:// creativecommons.org/licenses/by/ $4.0 /)$.

\begin{abstract}
Circular economy is emerging as a regenerative concept that minimizes emissions, relies on renewable energy, and eliminates waste based on the design of closed-loop systems and the reuse of materials and resources. The implementation of circular economy practices in resource-consuming agricultural systems is essential for reducing the environmental ramifications of the currently linear systems. As the renewable segment of circular economy, bioeconomy facilitates the production of renewable biological resources (i.e., biomass) that transform into nutrients, bio-based products, and bioenergy. The use of recycled agro-industrial wastewater in agricultural activities (e.g., irrigation) can further foster the circularity of the bio-based systems. In this context, this paper aims to provide a literature review in the field of circular economy for the agrifood sector to enhance resource efficiency by: (i) minimizing the use of natural resources (e.g., water, energy), (ii) decreasing the use of chemical fertilizers, (iii) utilizing bio-based materials (e.g., agricultural/livestock residues), and (iv) reusing wastewater from agrifood operations. The final objective is to investigate any direct or indirect interactions within the water-energy-nutrients nexus. The derived framework of synergetic circular economy interventions in agriculture can act as a basis for developing circular bio-based business models and creating value-added agrifood products.
\end{abstract}

Keywords: agrifood sector; agricultural waste; bioenergy; biofertilizers; wastewater; water reuse; resource management; circular economy; bioeconomy

\section{Introduction}

As the world population is estimated to reach 9.7 billion (approximately 25\% growth in current population) in 2050 [1], the increased consumption of primary natural resources (e.g., water, energy, raw materials) to cover the growing needs will undoubtedly lead to an unstainable ecosystem [2]. In light of this challenge, Circular Economy (CE) has emerged a non-linear regenerative concept that minimizes emissions, relies on renewable energy, and eliminates waste through the careful design of closed-loop systems and the recycling and reuse of materials and resources [3]. Notably, Circular Economy is gaining traction within the policy-making, business, and academic circles [4,5]. CE was initially introduced by regulators for practitioners [6]. At a European level, CE has recently gained importance as the EU developed a CE Action Plan, which constitutes one of the main pillars of the European Green Deal for Sustainable Growth [7]. The CE Action Plan was introduced in 2015 and then evaluated and reshaped in 2020, highlighting that the CE concept is a critical ever-evolving topic for the EU [8]. In this respect, at an enterprise level, innovative CE business models should be developed to replace the existing linear ones with the aim to design closed-loop supply networks and create sustainable products $[9,10]$. At an academic 
level, researchers in the CE field often have rather different disciplinary backgrounds [11]. Thus, a lack of a standard CE definition [12], and a conceptual framework for connecting CE and sustainable development $[13,14]$, is still evident in the literature.

Focusing on the agrifood systems, agriculture is the largest consumer of the world's freshwater resources (accounting for 70\% of the global water withdrawals), while more than one-quarter of the energy used globally is attributed to food production and supply $[15,16]$ Water and energy footprints, as environmental indicators, are critical in terms of agricultural sustainability $[17,18]$. Further considering that food demand is expected to increase by 59-98\% between 2005 and 2050 [19], the implementation of CE practices in agriculture is considered critical to eliminate the ramifications of the currently linear agrifood systems on the environment. In this respect, the CE principles for agriculture include: (i) the reduced use of primary natural resources (e.g., water, energy) throughout the crop production and animal farming processes, (ii) the minimization of polluting activities (e.g., synthetic fertilizers' use), and (ii) the recycling, transformation, and reuse of agricultural waste to produce bioenergy, nutrients, and biofertilizers [20]. However, transforming the CE concept from a theoretical framework into an integrated practical approach for the agrifood sector is still challenging [21].

With respect to agricultural waste management, bioeconomy can be considered as "circular by nature" [22] and "the renewable segment of the CE" [23]. In fact, bioeconomy refers to the production of renewable biological resources and their transformation into nutrients, bio-based products, and bioenergy [24]. Notably, agriculture accounts for approximately $62 \%$ of the total biomass supply in the EU [25]. In the US, India, and China, the exploitation of agricultural residues derived from cereal crops, such as wheat, maize, and rice, while novel techniques for the agricultural waste recovery have been developed [26,27]. Except for the crop residues, the livestock waste, such as cattle, pig, and poultry manure, may constitute an important source for the production of bio-based products [28]. To that end, the development and implementation of circular bio-based business models are imperative for creating value-added products and improving resource efficiency [29]. However, except for creating innovative bio-based solutions, ensuring the necessary amount of biological resources for substituting fossil feedstock is demanding [30]; although future agricultural productivity is expected to meet the growing food demand, the demand for bio-based materials is often neglected. At the same time, the use of recycled agro-industrial wastewater in agricultural activities (e.g., irrigation) may increase the circularity of the biobased systems [31]; dairy wastewater can be particularly challenging due to its high organic load that increases eutrophication. By limiting its use as fertilizer, soy products' wastewater can be a source of organic nutrients (e.g., proteins, oligosaccharides, isoflavones) and minerals.

According to the abovementioned, part of the essential resource categories (wastewater, and nutrients) of various circular systems have been reviewed separately in the past, regarding agricultural systems [26,31]. To the knowledge of the authors, there is no comprehensive review that combines research focused on agricultural systems that use circularity of water, energy, nutrients, or any combination of them.

In this context, the present work targets to answer the following questions in a comprehensive manner:

1. How has CE been practically integrated into the agricultural and livestock sectors in terms of bio-based production (e.g., energy, fertilizers) and water reuse?

2. Which are the actual benefits of the proposed CE solutions for the agrifood industry in terms of sustainability?

3. Which are the interrelations within the water-energy-nutrients nexus?

Based on these questions, this paper aims to provide a review of the literature in the field of $\mathrm{CE}$ practices for the agrifood sector that enhance resource use efficiency by: (i) minimizing the use of primary natural resources (e.g., water, energy), (ii) decreasing the use of polluting synthetic fertilizers, and (iii) utilizing bio-based materials (e.g., agricultural residues) and recycled wastewater. The ultimate scope of the analysis is to investigate 
any direct or indirect interactions within the water-energy-nutrients nexus to provide a conceptual framework for synergetic CE interventions. Notably, the system boundaries are set to include efforts in which both the inputs (e.g., agricultural waste, wastewater) and the outputs (e.g., treated water, bioenergy, biofertilizers) are derived from and used to agricultural activities, respectively.

The remainder of the paper is structured as follows. Section 2 captures the key inputs and outputs of agricultural systems to act as the basis for transforming from open-loop to circular models. Section 3 focuses on reviewing the sustainability benefits of CE and bio-based applications in the agrifood sector to develop a comprehensive framework for water-energy-nutrients synergies. Finally, Section 4 concludes with a discussion of managerial insights and suggestions for future research directions.

\section{System Mapping}

Agricultural systems require major inputs, such as water [32], energy [33], and nutrients [34]. Focusing on freshwater resources, water is provided in the crops through precipitation in the form of rainwater [35], as well as through irrigation in the form of surface or groundwater [36] or reclaimed water after wastewater treatment [37]. To support the sustainable management of water supplies in agriculture, several practices have been proposed. For example, the use of rainwater in regions with increased precipitation could reduce irrigation needs and reduce surface and groundwater depletion [38]. However, the seasonal variation of rainfall should be considered when designing rainfed systems [39]. To that end, a supplemental precision irrigation system could be meaningful [40]. Even in water-scarce regions, techniques including drip [41] or deficit irrigation [42] could support efficient water use. Besides, the use of treated wastewater (i.e., from municipalities, agricultural drainage, animal production facilities, agricultural/industrial processing) could be a sustainable solution of freshwater preservation due to water reuse [43]. However, in this latter case, the farmers' willingness to use and pay for treated wastewater should be considered [44].

In terms of energy resources, energy is essential for irrigation (e.g., groundwater pumping) and wastewater treatment [45], as well as for machinery power and fertilizers' production [46,47]. Several energy sources (e.g., fossil, hydropower, wind, sun, geothermal, and biomass) can be utilized [48]; Farmers usually use the energy provided from the national electricity mix [49]. To avoid fossil energy consumption, growers may exploit renewable energy sources, such as solar [50] or geothermal energy [51], indicatively using on-site installations in greenhouses [52,53]. At the same time, the use of biomass from agricultural residues (also known as yellow biomass) or/and other types of biomass (i.e., green and woody) is used as an alternative sustainable option for replacing fossil fuels in agriculture [54,55]. The respective bioenergy can be produced locally and used directly on-site or at national level powering the electrical grid and then used indirectly [56]. Moreover, except for the agricultural waste [26], specific energy crops (e.g., rapeseed, sunflower, miscanthus, and switchgrass) $[57,58]$ or any combination of them $[59,60]$ can be used to produce biofuels or bioenergy. However, given the dilemma between cultivating crops for biofuel or food when considering social, environmental, and economic parameters, the use of agricultural residues is proposed as a more viable alternative [61,62].

Concerning nutrients (e.g., nitrogen, phosphorus, potassium), farmers may use them directly on the soil (e.g., composted green waste or manure) [63,64], through soil amendments (e.g., biochar) [65], as well as through fertilizers [66]. The latter may refer to chemical/inorganic fertilizers, organic fertilizers, and biofertilizers [67]. Chemical fertilizers are generally categorized based mainly on their content in the basic chemical elements $\left(\mathrm{N}, \mathrm{P}_{2} \mathrm{O}_{5}, \mathrm{~K}_{2} \mathrm{O}\right)$ rather than in micro-nutrients which may be contained in traces or not [68]. Their valuable basic features include applicability, dissolution and quick nutrients release. On the other hand, several drawbacks are associated with them; such as the high potential for toxic concentrations and root burns and their leaching in surface or subsurface aquifers. In parallel, organic fertilizers are those connected to livestock waste and/or crop 
residues [69]. In this case, the fertilizers should be broken down into inorganic forms in the soil in order to be able to be absorbed by the plants. Finally, biofertilizers contain living micro-organisms which can create colonies in the rhizosphere of the plants when applied to the soil. Consequently, biofertilizers promote the plants' growth and increase the nutrients' availability [70].

Figure 1 summarizes the inputs and outputs of agricultural (crop and livestock) systems to be taken into account in this review. Emphasis is placed on reused water, bioenergy, and organic fertilizers/biofertilizers that constitute sustainable inputs to the system. These, at a first stage, should be produced by using the outputs of agricultural systems, such as crop (or livestock) residues and wastewater, and, secondly, be applied in crop and livestock production systems pointing out the circularity of these closed-loop systems. Urban or industrial wastewater was excluded from this system.

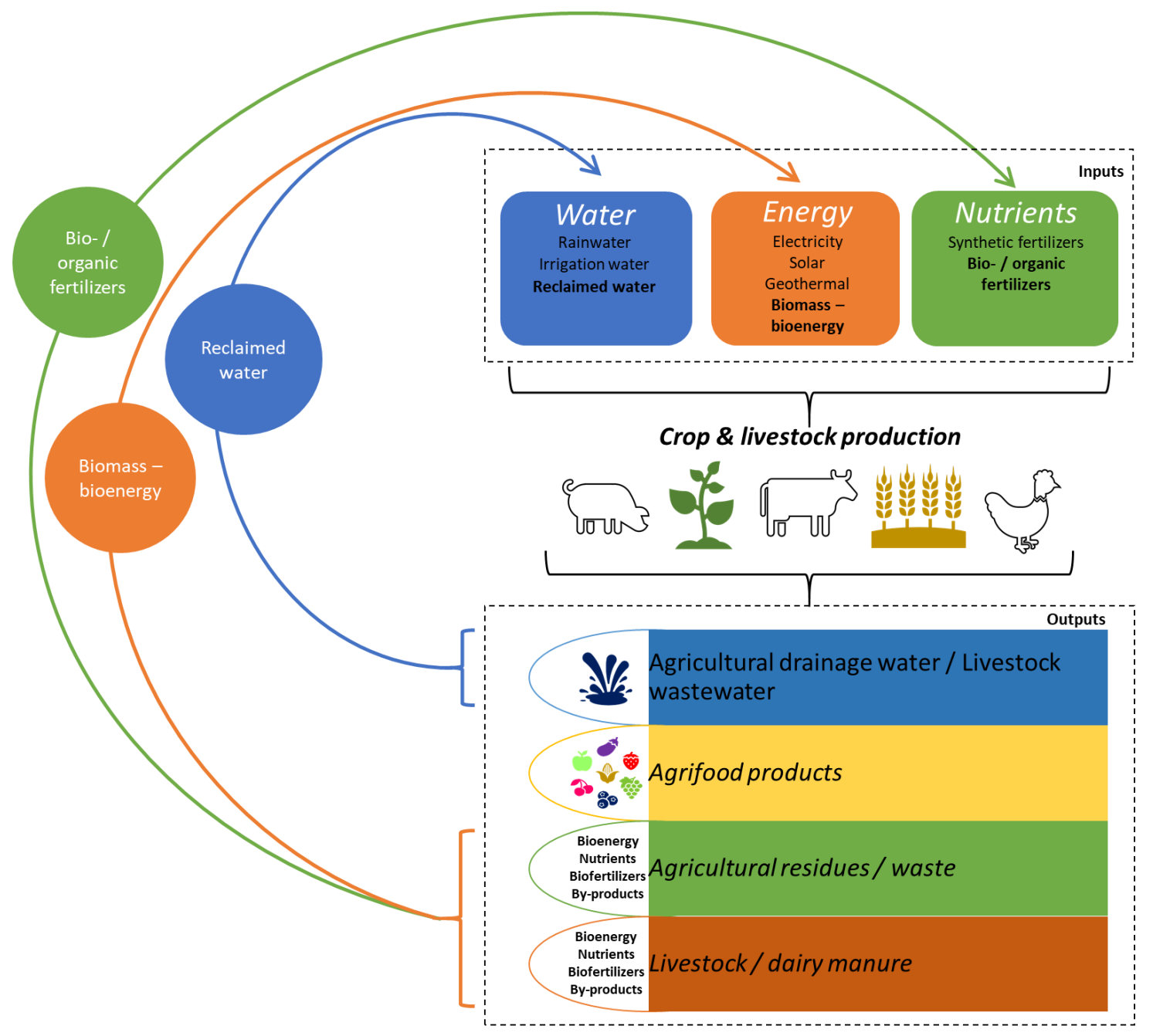

Figure 1. Boundaries (inputs and outputs) of the system under the circular economy framework in agricultural processes.

For the scope of this review, a series of literature-related eligibility criteria were set. More specifically, the studies should have been published: (i) in English, (ii) since 2015 up to now, and (iii) in peer-reviewed scientific journals. Although the term of CE has been introduced in both Europe and China by the 1990s, the current review focuses on the last six years to highlight the novelty and innovation that occurred recently, further considering the development of new technologies in agriculture. In this respect, this review does not constitute a complete or rigid collection of all CE studies in the agricultural sector but rather acts as a guiding map of the most pertinent state-of-the-art applications in the field. A total of 51 studies were included, retrieved from electronic databases, such as Scopus 
and Web of Science. The literature search was conducted in April-May 2020 and, for this reason, any newly published work after this period may not have been included. Finally, no grey literature is included (e.g., technical reports, dissertations).

\section{Resource Management Framework}

The extant literature of closed-loop solutions was classified according to the resource category that is related to, as follows: (i) water resources, (ii) energy resources, and (iii) nutrients. Based on this classification, a summary of the most novel scientific literature resources is categorized and presented below. After all, the water-energy-nutrients nexus is assessed given the limitations of each category.

\subsection{Water Resources}

Water represents one of the main resources that are used in agricultural processes [71]. Uses of water in agriculture include mainly irrigation for crop production systems and various other uses (e.g., animal water needs, washing services) in livestock systems [32]. To promote freshwater sustainability, several research efforts have focused on issues, such as irrigation scheduling and control, by incorporating novel technologies (e.g., Internet of Things, neural network models) [72-75]. Notably, this planning is directly connected with the crop freshwater requirements and the local climatic and geographical conditions [42,76]; the combination of annual precipitation with irrigation water should meet the annual crop water needs. Beyond optimized precision agriculture scheduling, the use of reclaimed/treated wastewater could enhance freshwater sustainability. In this context, we review the main research efforts focusing on the reuse of agricultural wastewater (i.e., drainage water) or livestock one in crop production systems to enlighten the $\mathrm{CE}$ perspective in the field. To that end, a series of closed-loop solutions related to irrigation water is presented.

Agricultural primary or secondary processing facilities usually produce wastewater that may be applied to crops for enhancing soil properties after appropriate processing [31]. A relevant study aimed to evaluate the reuse of wastewater coming from olive mill, as a whole soil conditioner and fertilizer in olive grove [77]. Under the experimental trials, various doses in successive years have been applied, resulting in a positive effect on soil features and olive yield, while no negative impact presented on oil quality parameters. Concerning animal-based wastewater, the application of swine wastewater (i.e., pig slurry) on a soybean crop increased soil nutrient, reducing the need for mineral fertilization [78]. However, the authors highlight the need to monitor nutrients leakage to groundwater, as some of them may downgrade water quality.

In addition, agricultural wastewater may be used purely for irrigation purposes after removing any existing pathogens [79]. Indicatively, greywater (which may also result from agriculture) is used for irrigation in a Romanian red pepper farm [80]. The authors consider that the farm's competitiveness can increase in case greywater resources substitute freshwater consumption. Thus, using data from the red pepper farmer, authors perform a simulation of virtual farms (resembling the real one to different degrees of greywater consumption) to generate a representation of a more comprehensive system to find a threshold above which farms obtain economic benefits regarding the greywater use. In another simulation study, located in farms near the Nile Delta, the optimization revealed that the reuse of agricultural drainage water could approximately satisfy $30.8 \%$ and $29.1 \%$ of the total irrigation requirements during summer and winter, respectively [81]. In a similar study in South Korea, the agricultural drainage water quantity reused represents $49.1 \%$ and $54.5 \%$ of the irrigation needs (substituting canal delivery) during summer and winter, respectively [82].

In general, wastewater reuse can significantly contribute to the circular transformation of the agrifood sector. Although the research in the field seems to be limited, the use of wastewater as a soil conditioner or as a source for substituting freshwater use in irrigation could be promising for closing the loop in agriculture. Notably, according to the system 
boundaries and in terms of circularity, this review was limited to wastewater deriving from agricultural or livestock activities; in case municipal and industrial wastewater is further considered, the potential and the positive impact of the practice could be increased [83].

\subsection{Energy Resources}

Energy consumption in agricultural processes is among the most significant factors that inevitably contribute to crop production systems and their related field operations. The highest energy consumption is related to field machinery use, fertilizers and agrochemicals application, and other field operations, such as harvesting and irrigation [59]. Of course, this fact directly impacts on the environment and, consequently, energy resources should be among the primary resources to be considered under a CE framework. In this context, a series of existing publications have been incorporated into this review, focusing on closed-loop systems in agriculture related to energy and greenhouse gases emissions.

An overall supply chain evaluation is always a promising tool for policy makers not only in conventional agricultural systems, but also in closed-loop ones [84-86]. A closedloop supply chain optimization has been attempted in citrus crop by using a mathematical model under the objective of minimizing cost and carbon footprint [87]. Regarding logistics operations, in the cases where multiple vehicles were used, the emissions were reduced. Similarly, a food waste-to-energy-to-food approach was conducted, including an energy flow analysis of four stages (i.e., agricultural production, processing/packaging, distribution and consumption) in food supply chains was performed regarding various food categories [88]. In this study, the authors concluded that embodied energy loss is up to $17 \%$ of the total primary energy demand. To produce one $\mathrm{kJ}$ of nutritional energy, $8.7 \mathrm{~kJ}$ of primary energy is required with the most critical stages being the distribution and agricultural production.

Apart from a generic supply chain representation of closed-loop crop production systems, livestock residues are used to produce green energy that may return to the agricultural system. Toop et al. proposed the design and implementation of micro-scale anaerobic technology applied on broiler chicken farms in the UK and Ireland [63]. Among their main objectives was to transform the produced chicken manure and bedding substrate materials (such as wood chips and straw) into energy (heat and power) for the local farmers' needs. Similarly, except for the potential energy production by using poultry manure, other livestock units may provide possible solutions for green energy production. An on-site anaerobic digestion system in a Brazilian dairy cattle farm was techno-economically assessed [89]. In particular, the co-digestion of cattle manure and sweet potato for the production of biogas and its use in local farms was analyzed. Specifically, the scenario of the maximum quantity of sweet potato mixed with dairy cattle manure produced biogas capable of generating about 2.4 MWh daily. The conversion of mixed manures (chicken and poultry) to bioenergy has been studied to cover the fuel needs for electricity and transport in an average dairy farm and the associated facilities [90]. For this scope, the average biogas to fulfil the needs of each unit was estimated to be $4163 \mathrm{MJ}$ per day, while the presented results showed that the anaerobic digestion plant had the potential to provide biogas to about 22 dairy farms.

Moreover, agricultural waste may also come from crop production processes. In such a case, the generation of biogas production by cotton crop residues (i.e., straws) was investigated [56]. The generated bioenergy of an one-hectare field can be more than $4 \mathrm{MWh}$ of energy annually with the local cotton processing enterprises to be the potential end-users. A more complex system that produces energy by the digestion (with the use of a small scale anaerobic digestion unit) of agricultural waste and wood chips is assessed for covering the heating needs of an aquaponic greenhouse [91]. This system presented up to $30 \%$ lower energy costs compared to the conventional heating system. A closed-loop system in an olive farm combined with olive mill may extract from the olive grove and olive mill up to 13 and 11 tons of liquid and gas fuel, respectively, in order to be further used on farm level [92]. 
However, crop residues represent only a portion of feedstock sources for bioenergy production and circularity in agriculture; more complex systems that use multiple resources exist. Such a system was assessed with the use of life cycle assessment (LCA) of the transformation of agrifood industry waste (i.e., crops residues and livestock manure) along with energy crops (i.e., maize and rye) into energy production in biogas plants [93]. The location of the biogas plant in relation to the agrifood processing plant ensures that the heat can be transferred for the needs of the agrifood processing plant and the associated farms. An expanded LCA analysis in the form of multidimensional sustainability assessment was also performed in a decentralized farm-scale anaerobic digestion system [66]. In this case, a mixture of pig slurry, food waste, slaughterhouse waste and grass silage was used as feedstock for biogas production. The avoidance of fossil energy resources through biogas production and utilization offers a circular potential to the local agricultural regions. Finally, an additional closed-loop system is evaluated with LCA; this system includes a pig farm, a dragon fruit, a forage, a mushroom plantation, a fishery unit, a biogas generation unit, and an organic fertilizer production unit [94]. According to the results, the circular agriculture model presents similar or worse results than the conventional agriculture model if the potential environmental impacts are considered. However, this fact does not imply that a circular agriculture system has zero emissions. In general, circular systems should be evaluated from a wider perspective, taking into consideration all system components.

Overall, based on the reviewed research studies, it could be concluded that energy and emissions assessment approaches should be integrated into CE systems in agriculture. Given the boundaries set in this review, only a few studies comply with them. This fact may highlight the significant potential in this area and showcase the complexity of agricultural systems that circulate renewable energy resources, such as biomass. Complex systems that combine various types of inputs emerge as promising in bioenergy production, though without avoiding the key principles that should be followed for the development of circular agriculture, namely reduce, reuse, and recycle [95]. These basic principles should be further assessed under specific local constraints of each system under study.

\subsection{Nutrients}

Agricultural processes in crop and animal science embrace the nutrients' cycle. A basic principle in nature is the law of conservation of matter; based on this, nutrients' management in agriculture is of high importance under the scope of CE. The process options, which may improve nutrients' management and recover residual nutrients to high-quality products, can be achieved by efficient nutrient use and show off the key challenges that should be faced [96]. In this light, a series of scientific research related to systems that circulated nutrients under this review's constraints are presented below.

Beginning with the livestock-based inputs through the prism of $\mathrm{CE}$, the anaerobic digestion of one cubic meter of pig manure can produce $49.4 \mathrm{~kg}$ of biofertilizer [97]. This type of biofertilizers can improve the resource use efficiency and the sustainability of agricultural farms [98]. Of course, certain agronomic and legislative guidelines should be followed to distribute any kind of manure in fields. Targeting the minimization of the annual cost of manure distribution on wheat and maize crops, a reduction up to $6 \%$ in the annual cost was achieved [99]. Liquid manure application was used to enhance soil condition and replace partially or exclusively chemical fertilizers. In particular, chicken manure has been converted into fertilizers by using a decentralized screw pyrolysis reactor [100]. Going even further, a post-processed animal waste (i.e., calcined bone) was utilized to subtract phosphorus and reintroduce it in the form of foliar fertilizer with a dose of $3 \mathrm{~kg} \cdot \mathrm{ha}^{-1}$ in the cultivation of maize plants [101]. This dose positively impacted plants growth (both above and below ground), while the maize grain production was positively affected up to $600 \mathrm{~kg} \cdot \mathrm{ha}^{-1}$.

Regarding the crop-based input, the studies can be divided into those related to either primary or secondary production processes. More specifically, various maize production scenarios with catch crops rotation and different fertilization systems were analyzed; the 
analysis concluded that the replacement of a significant percentage of the mineral fertilizers with digestate could contribute among others to offset resource depletion (94-96\%) and ozone depletion (96-99\%) [102]. Furthermore, the effects of various management systems under different inputs on the nutrients soil content and mineral content on olive trees have been assessed [103]. In terms of the soil organic matter, nutrients were significantly improved after consecutive years of biomass incorporation. A similar application of crop residues, set as mulch on the ground, was assessed in two plant species (i.e., turnip and barley) regarding soil nitrogen availability [104]. The fixed nitrogen by the legume crops varied from 79.7 to $187.5 \mathrm{~kg} \mathrm{~N}$ per hectare. In the upcoming year, the available soil nitrogen was increased. However, in case high nitrogen content biomass is used, mulching may have adverse effects due to ammonia volatilization risk. In greenhouse crops (e.g., tomato and pepper), crop waste may be transformed to some extent in green fertilizer [105]. Finally, in the case of the use of various types of algal species, biomass has been assessed regarding soil aggregate stability, nutrients, and overall crop growth and yield, showing that this type of biomass has a significant effect on soils used in agriculture [106].

In addition, there are significant research efforts related to secondary agricultural production processes or further processing (e.g., digestion) of the primary input before it is reintroduced to the agricultural system. In the first case, after the industrialized bioenergy production by crop residues, the by-product could be used as a biofertilizer in crop production $[56,63,89]$. The use of such a fertilizer from corn straw may profoundly reduce the greenhouse gas emissions up to $80 \%$ [107]. During the secondary processing of agricultural products, a significant perspective for recycling nutrients exists. Residues produced across the wine production chain (i.e., stalks, seeds, pomace) constitute a promising example, especially for the Mediterranean countries [108]. More specifically, the high amounts of pomace (with high content in several nutrients) could be used solely or combined with other material as compost for increasing the organic matter in the soil. By-products from cardoon and cotton, as potential growth substrates for Cichorium spinosum, have been assessed in comparison with (or in combination with) zeolite as a soil amendment, showcasing promising results in production costs and yields [109].

As abovementioned, part of the research is related to biofertilizers produced after further being processed. In these cases, the input in the system may come either from crop production or from the combination of crop and livestock production. The production of biochar by cotton straws indicated that a field of an one-hectare area might produce up to $130 \mathrm{~kg}$ of biochar annually to be used as an amendment for cotton growth and improve soil condition, decreasing the use of conventional fertilizers up to 50\% [56]. Treatments with enriched biochar significantly improved soil organic matter up to $514 \%$ and macronutrients up to $230 \%$, compared to the non-enriched biochar and control operations. This affected total biomass yield which varied from $75-85 \%$ compared to the conventional chemical fertilizers [65]. The sustainability of the conversion of olive pruning waste into by-products (i.e., biochar) was investigated based on a novel thermocatalytic reforming process [110], while 11 tons of biochar were produced in a closed-loop olive mill-grove system after pyrolysis processing [92]. The use of rice husks for generating ash as fertilizer was further proposed [111]. The authors concluded that the utilization and processing of waste of various rice value chains improve sustainability performance. Other authors focused on the production of organic fertilizer under various compost rates, produced by rice bran and husks [112]. Their results indicated that rice plants in all compost treatment processes had increased growth (i.e., the height varied 8-64\%), while the produced biomass was 32-113\% more compared to the untreated plants.

On the other hand, the production of biofertilizers based on anaerobic digestion was produced by mixed agricultural wastes, including pig manure $(43 \%)$, cow manure $(20 \%)$, maize and triticale silages (25\%), and cereal bran (12\%) [113]. The produced biochar was rich in macronutrients, suitable for enhancing soil fertility. Another study presented the production of digestate stemming from anaerobic digestion processing of chicken and poultry manure to be used in crop production as fertilizer [90]. Different mixtures 
of agricultural wastes applied as substrate supplement on mushroom crop production increased yield by $11 \%, 26 \%, 30 \%$, and $42 \%$ in the first application and by $86 \%$ and $31 \%$ in the second one compared to the control substrate [114]. The use of biochar produced by fruit, vegetable, and nutshell waste is another application of biofertilizer in wheat plants. $0.5 \%$ mixture of biochar gave the optimum wheat growth, between $0.5 \%$ and $1 \%$ gave almost similar results, while higher than $1 \%$ might suppress the growth of wheat plants [115]. The effect of various doses of two bio-waste based fertilizers on soil properties and pasture production was assessed compared with conventional practices [116]. The obtained results showed that the high doses of the organic fertilizers improved soil fertility and increased pasture production.

A series of research points out the use of mixed organic waste under the scope of $\mathrm{CE}$ in agriculture. The utilization of recycled waste, such as animal-based residues and various types of manures, along with the application of organic fertilizers, can enhance efficiency during crop production. Notably, the agrifood system efficiency was $3-21 \%$ higher in the case of the circular use of resources compared to the traditional consumption of raw materials [117]. To this scope, dairy manure, combined with sweet potato for the production of biofertilizers, led to the production of about 20-27 tons of N, P, and K annually [89]. The combination of green manure with various types of agricultural waste by-products was evaluated and compared with a commercial organic fertilizer [118]. Chicken manure and palm oil mill effluent (i.e., treated and untreated) were applied as an organic fertilizer in Ipomoea aquatica plants grown in pots [119]. Various treatments were assessed, and the presented results were both positive (higher than $50 \%$ of fresh biomass than control plants) and negative (retarded growth due to high concentration in residual oil). Moreover, pig manure and mushroom slag in a dragon fruit production system were evaluated [120]. When the breeding of pig was increased by $10 \%$, the average economic output and resource efficiency of the system would increase annually by $0.2 \%$ and $0.66 \%$, respectively. In case that the planting of dragon fruit was increased by $10 \%$, the corresponding parameters would decrease annually by $0.17 \%$ and $0.57 \%$, respectively.

Finally, given that food products undergo minor or major processing after agricultural production, nutrients recycling may also be derived from food waste. In this case, by using anaerobic digestion for food waste nutrients recycling, after testing various concentrations of the digestate, the research concluded that the results were not significantly different from the case of applying commercial fertilizers [121].

Nutrients circularity is considered to play a significant role in CE-based systems in agriculture. There have been enough research applications based on crop or livestock input or combinations of them; part of nutrients produced after minor or major processing. This fact showcases that fertilization, especially in crop production systems, is one of the main resource-consuming categories. Synthetic fertilizers have a negative environmental, financial and, even social impact on crop production, highlighting the need for organic/biological alternatives under the scope of CE principles. The combination of various types of manures, crop residues, but also food waste is an indicative example. However, agricultural and food waste management will always evolve towards nutrients circularity research and applications.

\subsection{Water-Energy-Nutrients Nexus}

As abovementioned, the main pillars in designing a CE-based agricultural system are water, energy and nutrients. It is profound that there are various correlations and links between these pillars, creating technological bases for sustainable economic and social development (Figure 2). For example, in most cases when water treatment is under study, apart from the water that is supposed to be used for irrigation purposes, there will be a by-product that may be exploited as fertilizer after specific treatment. 


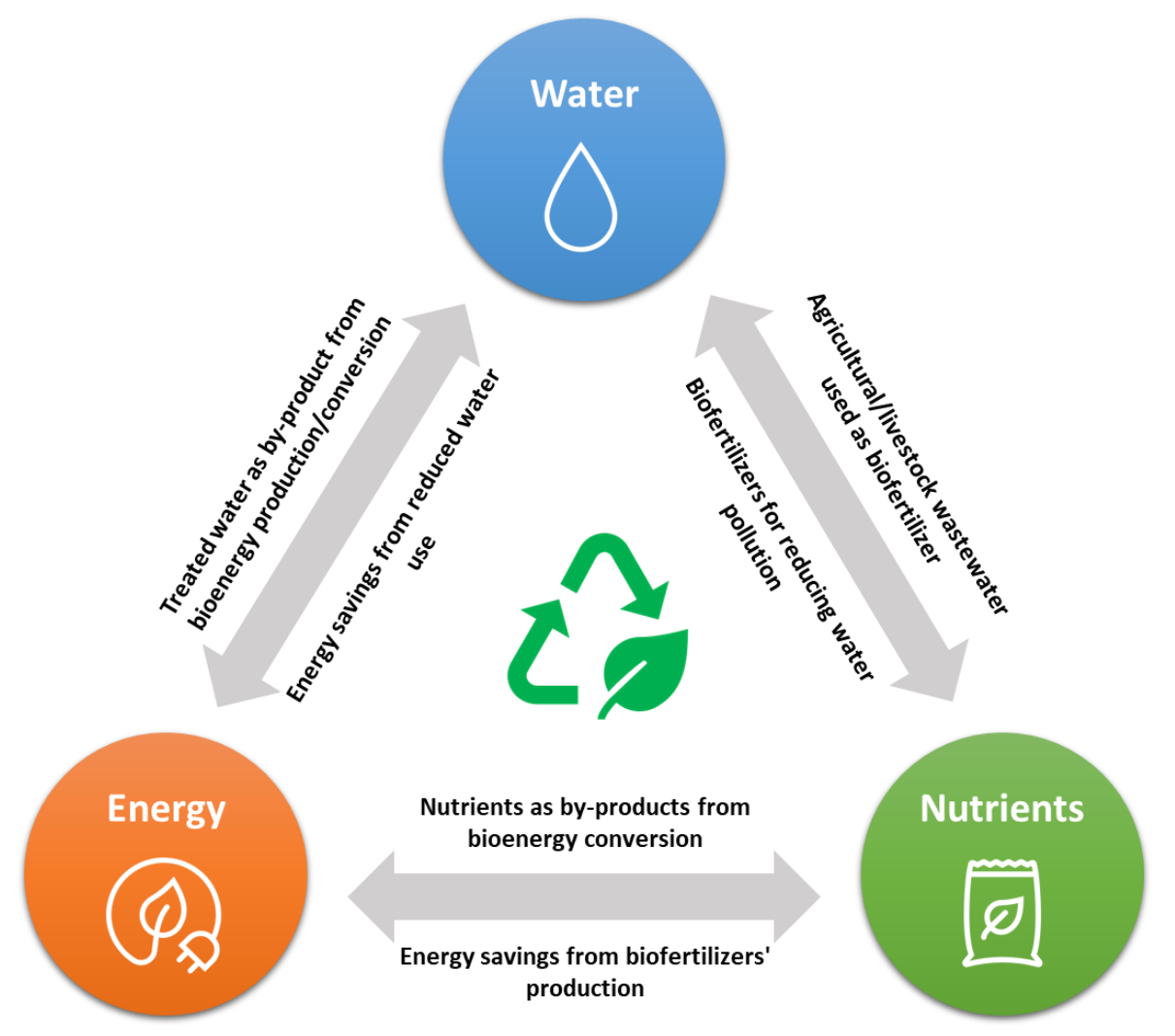

Figure 2. Potential Water-Energy-Nutrients synergies in agriculture.

In literature, there are research studies that profoundly target on the whole waterenergy-nutrients nexus. The identification of operational and resource inefficiencies in a mango food supply chain may have substantial financial and environmental benefits in realtime when a CE-based redesigning is implemented [122]. Similarly, the potential of circular agriculture is assessed in an individual farm taking into account financial, environmental, and social factors resulting, in the fact that circular agriculture can be achieved mainly based on economic viability [123]. Undeniably, these are only indicative research studies pointing out the linkages between water, energy, and nutrients without implying that the nexus does not exist in the rest of the reviewed studies.

\section{Discussion}

In the present review, 51 research studies were included in total. Those were retrieved from various journals, such as "Sustainability", "Journal of Cleaner Production", "Resources, and conservation and recycling", "Agronomy". Among all these studies, the majority $(73 \%)$ were case studies assessment, while approximately half of them (49\%) referred to European conditions, with the rest referring to Asian (24\%) or other regions.

Generally, closed-loop (or circular) agriculture is one of the most promising solutions for facing the resources' use throughout crop and livestock production processes. Various applications have been developed by recycling water, energy and nutrients from crop and livestock systems and reuse them after required processing in agricultural systems. Concerning the provenance of the resources, the literature focuses on six discrete categories, with the most popular being the crop residues-related which includes 18 references, seconded by wastewater-related which contains 11 (Figure 3). Of course, livestock manure represents an additional category, while there are references that combine more than one of the abovementioned categories, such as various types of manure with crop waste or energy crops. Food waste is referenced in the reviewed papers only in 2 cases. The reuse of food waste for agricultural purposes seems to be relatively low even though it could be a significant source of nutrients for various crops. 


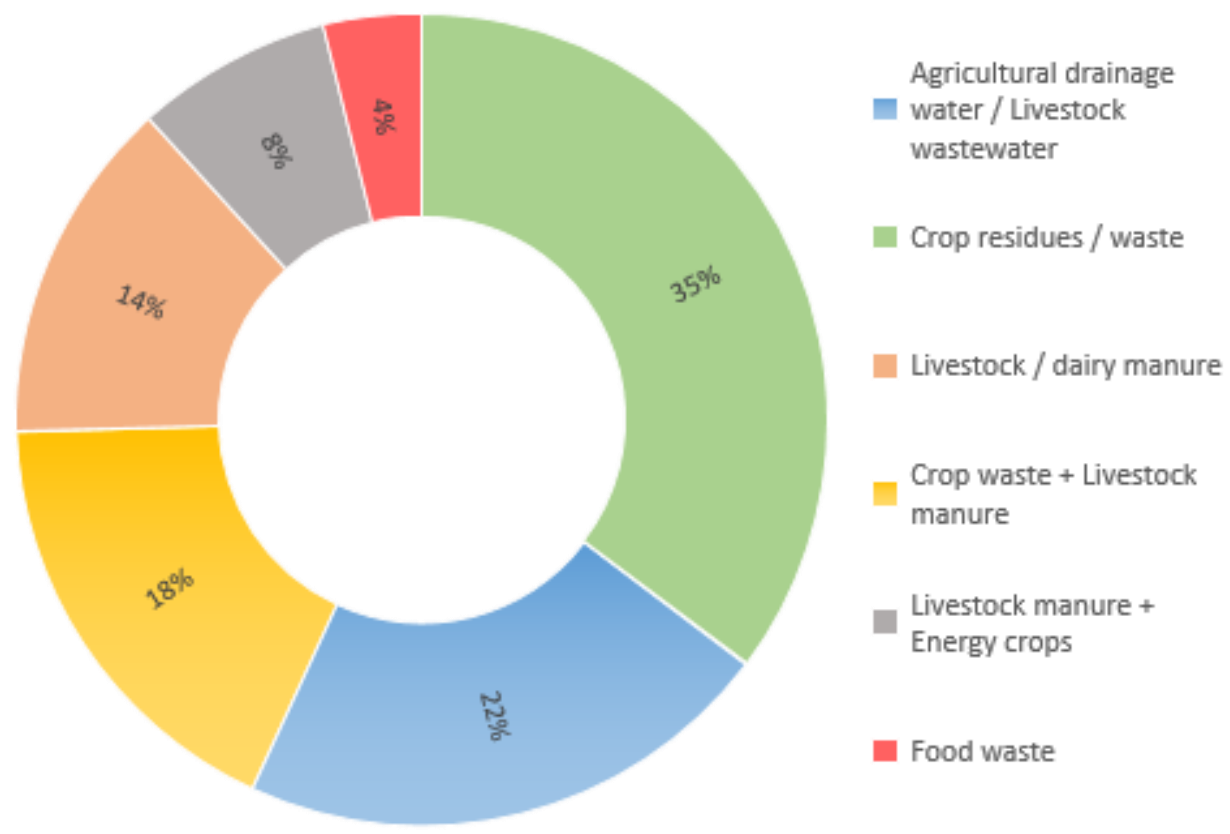

Figure 3. Input-related allocation regarding the various closed-loop systems.

Given the various inputs inserted into a crop/livestock production system, specific resources can be extracted, as outputs of the system, namely water, energy, and nutrients. At an ensuing step, these resources will be recycled or reused in the same or another agricultural system. In this review, the most highly referenced output category is nutrients with 28 references, 9 articles discuss about water, 5 about energy, and 9 include both energy and nutrients circularity (Figure 4). Fertilization is among the most consuming field operations concerning energy and cost without excluding the environmental impact. This is the key reason that most of the reference focus on nutrients circularity applications, by avoiding as much as possible synthetic fertilizers. Reference that combines both energy and nutrients as outputs they incorporate, in most cases, anaerobic digestion systems in order to produce biogas and fertilizer as by-product from the digestion process. Overall, these outputs will be the inputs to other agricultural systems, closing the resources' cycle loop.

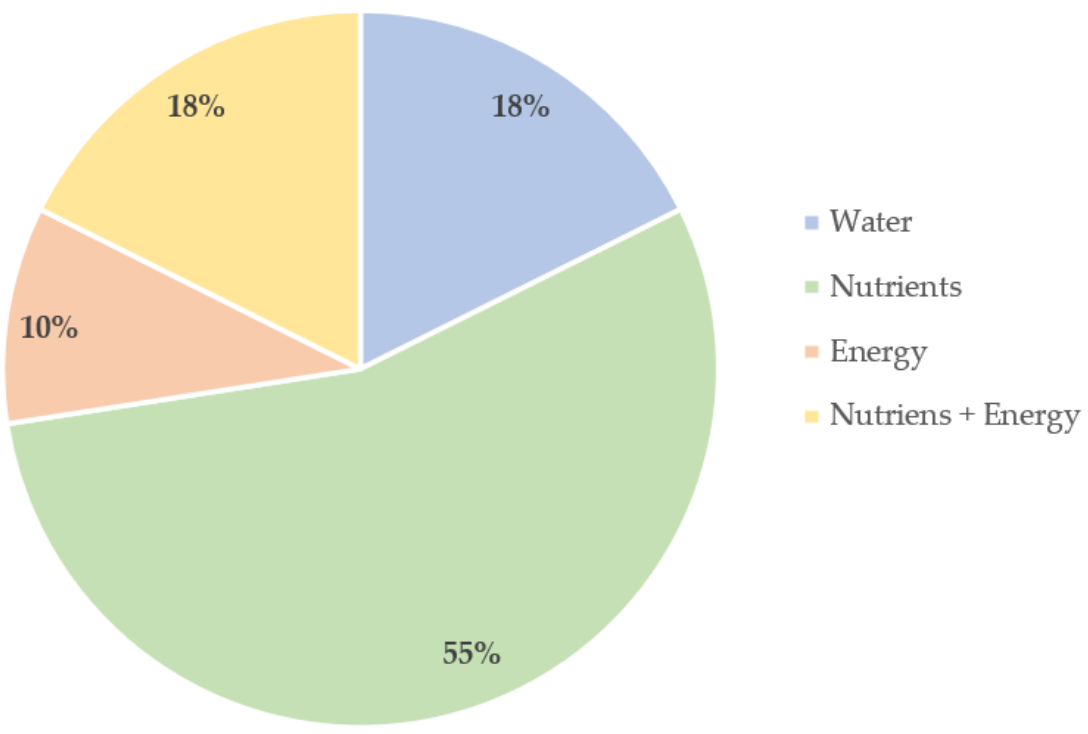

Figure 4. Output-related allocation regarding the various closed-loop systems.

Based on the literature reviewed in the current work, the resources were reused in a wide variety of crops (Figure 5). In most studies, the resources were applied in diverse 
crops (13 studies), 10 in cereals, 8 in orchard crops, 7 in vegetable crops and the rest in other types, including livestock production systems. This allocation intimates that the reuse of resources is applicable in almost any kind of crop, given the specific features of each closed-loop system.

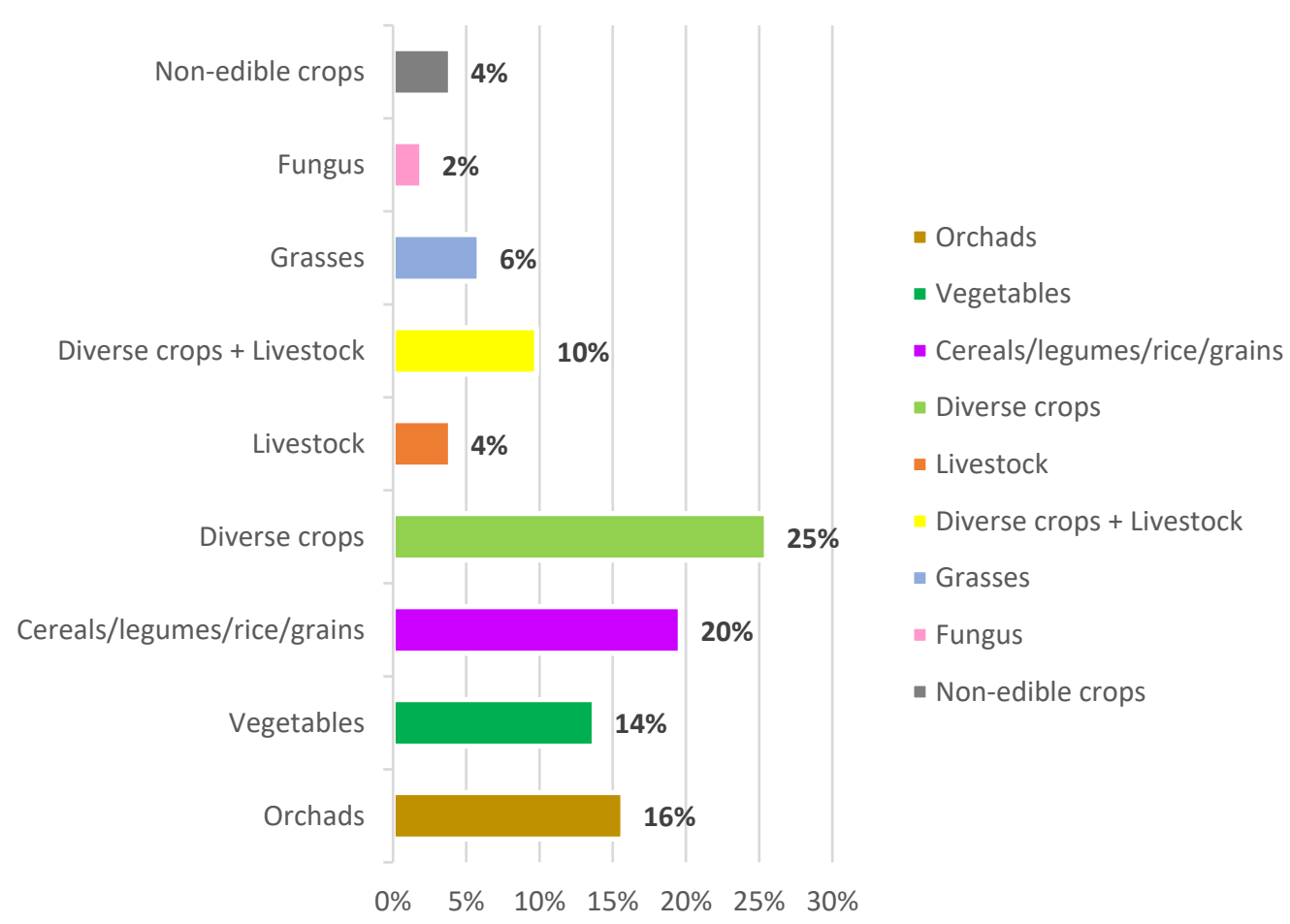

Figure 5. Allocation of resources to crops/livestock systems.

\section{Conclusions}

The analysis conducted in the framework of the present review reveals an existing trend, not only in the associated research community but also in the farming business. Indicatively, farmers, policy makers, and agronomists recognize the necessity for $\mathrm{CE}$ in agriculture and propose and implement solutions based on this concept. The benefits resulting from the reuse of resources are indicatively natural resources savings (including energy), reduction of GHG emissions due to the production of synthetic fertilizers, reduction of fossil fuels use and even more. It is indisputable that the associated parties (e.g., farmers, agronomists) should invest adequate capital to create the right circumstances towards a closed-loop system. However, in the long term, the actual benefits will be higher for the whole system. Overall, the water-energy-nutrients nexus includes significant correlations among them. For instance, a livestock production unit with manure treatment facilities may produce bioenergy (biogas), and fertilizer as by-product, while the treated water that is enriched with nutrients is suitable to be applied in specific crops under specific conditions. Apart from the resources synergies presented throughout the review, further steps should be realized to create strong bonds under the scope of CE between the food industry and agriculture. Food waste quantities are massive globally. Apart from the other uses that recycled food may already have, there is a high potential for organic fertilizers production or even co-digestion with other wastes for bioenergy production. In the future, more CE-based applications in agriculture are expected to focus on different types of secondary food sector wastes to be reuse in agriculture. Still, it is even more crucial to advance not only on efficiency and functionality of such closed-loop systems but also on research and innovation. 
Author Contributions: Writing-original draft preparation, E.R. and E.A.; methodology, E.R. and D.B.; investigation, E.R. and E.A.; conceptualization E.A. and D.B.; writing-review and editing, E.R., E.A., C.A., D.A. and D.B.; supervision, D.B. All authors have read and agreed to the published version of the manuscript.

Funding: This research has been funded by the Horizon 2020 project "NAIADES", GA number: 820985.

Institutional Review Board Statement: Not applicable.

Informed Consent Statement: Not applicable.

Data Availability Statement: Data sharing not applicable.

Conflicts of Interest: The authors declare no conflict of interest.

\section{References}

1. United Nations. World Population Prospects 2019: Highlights; United Nations: New York, NY, USA, 2019.

2. Benos, L.; Bechar, A.; Bochtis, D. Safety and ergonomics in human-robot interactive agricultural operations. Biosyst. Eng. 2020, 200, 55-72. [CrossRef]

3. Ellen MacArthur Foundation. Towards the Circular Economy; Ellen MacArthur Foundation: Cowes, UK, 2013.

4. Geissdoerfer, M.; Savaget, P.; Bocken, N.M.P.; Hultink, E.J. The Circular Economy-A new sustainability paradigm? J. Clean. Prod. 2017, 143, 757-768. [CrossRef]

5. Velenturf, A.P.M.; Archer, S.A.; Gomes, H.I.; Christgen, B.; Lag-Brotons, A.J.; Purnell, P. Circular economy and the matter of integrated resources. Sci. Total Environ. 2019, 689, 963-969. [CrossRef] [PubMed]

6. Murray, A.; Skene, K.; Haynes, K. The Circular Economy: An Interdisciplinary Exploration of the Concept and Application in a Global Context. J. Bus. Ethics 2017, 140, 369-380. [CrossRef]

7. European Commission. Communication from the Commission: The European Green Deal. COM(2019) 640 Final 2019; European Commission: Brussels, Belgium, 2019.

8. European Commission. A New Circular Economy Action Plan for a Cleaner and more Competitive Europe COM/2020/98 Final; European Commission: Brussels, Belgium, 2020.

9. Bocken, N.M.P.; de Pauw, I.; Bakker, C.; van der Grinten, B. Product design and business model strategies for a circular economy. J. Ind. Prod. Eng. 2016, 33, 308-320. [CrossRef]

10. Geissdoerfer, M.; Morioka, S.N.; de Carvalho, M.M.; Evans, S. Business models and supply chains for the circular economy. J. Clean. Prod. 2018, 190, 712-721. [CrossRef]

11. Ghisellini, P.; Cialani, C.; Ulgiati, S. A review on circular economy: The expected transition to a balanced interplay of environmental and economic systems. J. Clean. Prod. 2016, 114, 11-32. [CrossRef]

12. Kirchherr, J.; Reike, D.; Hekkert, M. Conceptualizing the circular economy: An analysis of 114 definitions. Resour. Conserv. Recycl. 2017, 127, 221-232. [CrossRef]

13. D’Amato, D.; Droste, N.; Allen, B.; Kettunen, M.; Lähtinen, K.; Korhonen, J.; Leskinen, P.; Matthies, B.D.; Toppinen, A. Green, circular, bio economy: A comparative analysis of sustainability avenues. J. Clean. Prod. 2017, 168, 716-734. [CrossRef]

14. Millar, N.; McLaughlin, E.; Börger, T. The Circular Economy: Swings and Roundabouts? Ecol. Econ. 2019, 158, 11-19. [CrossRef]

15. FAO. The State of the World's Land and Water Resources for Food and Agriculture (SOLAW)—Managing Systems at Risk; FAO: Roma, Italy, 2011; ISBN 978-92-5-106614-0.

16. FAO. FAO Energy-Smart Food at FAO-An Overview; FAO: Roma, Italy, 2012.

17. Lampridi, M.; Kateris, D.; Sørensen, C.G.; Bochtis, D. Energy footprint of mechanized agricultural operations. Energies 2020, 13, 769. [CrossRef]

18. Lampridi, M.G.; Sørensen, C.G.; Bochtis, D. Agricultural sustainability: A review of concepts and methods. Sustainability 2019, 11, 5120. [CrossRef]

19. Valin, H.; Sands, R.D.; van der Mensbrugghe, D.; Nelson, G.C.; Ahammad, H.; Blanc, E.; Bodirsky, B.; Fujimori, S.; Hasegawa, T.; Havlik, P.; et al. The future of food demand: Understanding differences in global economic models. Agric. Econ. 2014, 45, 51-67. [CrossRef]

20. EMF. Cities and Circular Economy for Food; Ellen MacArthur Foundation: Cowes, UK, 2018.

21. Del Borghi, A.; Moreschi, L.; Gallo, M. Circular economy approach to reduce water-energy-food nexus. Curr. Opin. Environ. Sci. Health 2020, 13, 23-28. [CrossRef]

22. European Environment Agency. The Circular Economy and the Bioeconomy_Partners in Sustainability; Publications Office of the European Union: Luxembourg, 2018; ISBN 9789292139742.

23. Caudet, L.; von Hammerstein-Gesmold, V. A New Bioeconomy Strategy for a Sustainable Europe; European Commision Press Release; European Commision: Brussels, Belgium, 2018.

24. European Commission. Innovating for Sustainable Growth: A Bioeconomy for Europetee of the Regions Innovating for Sustainable Growth: A Bioeconomy for Europe; European Commission: Brussels, Belgium, 2012. 
25. Gurria, P.; Ronzon, T.; Tamosiunas, S.; Lopez, R.; Condado, S.G.; Guillen, J.; Cazzanigam, N.; Jonsson, R.; Banja, M.; Fiore, G.; et al. Biomass Flows in the European Union: The Sankey Biomass Diagram-Towards a Cross-Set Integration of Biomass; Publications Office of the European Union: Luxembourg, 2017.

26. Duque-Acevedo, M.; Belmonte-Ureña, L.J.; Cortés-García, F.J.; Camacho-Ferre, F. Agricultural waste: Review of the evolution, approaches and perspectives on alternative uses. Glob. Ecol. Conserv. 2020, 22, e00902. [CrossRef]

27. Mohan, S.V.; Chiranjeevi, P.; Dahiya, S.; Kumar, A.N. Waste derived bioeconomy in India: A perspective. New Biotechnol. 2018, 40, 60-69.

28. Caruso, M.C.; Braghieri, A.; Capece, A.; Napolitano, F.; Romano, P.; Galgano, F.; Altieri, G.; Genovese, F. Recent updates on the use of agro-food waste for biogas production. Appl. Sci. 2019, 9, 1217. [CrossRef]

29. Donner, M.; Gohier, R.; de Vries, H. A new circular business model typology for creating value from agro-waste. Sci. Total Environ. 2020, 716, 137065. [CrossRef]

30. Bos, H.L.; Broeze, J. Circular bio-based production systems in the context of current biomass and fossil demand. Biofuels Bioprod. Biorefining 2020, 14, 187-197. [CrossRef]

31. Wang, Y.; Serventi, L. Sustainability of dairy and soy processing: A review on wastewater recycling. J. Clean. Prod. 2019, 237. [CrossRef]

32. Aivazidou, E.; Tsolakis, N.; Iakovou, E.; Vlachos, D. The emerging role of water footprint in supply chain management: A critical literature synthesis and a hierarchical decision-making framework. J. Clean. Prod. 2016, 137, 1018-1037. [CrossRef]

33. Woods, J.; Williams, A.; Hughes, J.K.; Black, M.; Murphy, R. Energy and the food system. Philos. Trans. R. Soc. B Biol. Sci. 2010, 365, 2991-3006. [CrossRef] [PubMed]

34. Dungait, J.A.J.; Cardenas, L.M.; Blackwell, M.S.A.; Wu, L.; Withers, P.J.A.; Chadwick, D.R.; Bol, R.; Murray, P.J.; Macdonald, A.J.; Whitmore, A.P.; et al. Advances in the understanding of nutrient dynamics and management in UK agriculture. Sci. Total Environ. 2012, 434, 39-50. [CrossRef] [PubMed]

35. Gupta, R.; Tyagi, N.K.; Abrol, I. Rainwater Management and Indian Agriculture: A Call for a Shift in Focus from Blue to Green Water. Agric. Res. 2020, 1-15. [CrossRef]

36. Garcia-Caparros, P.; Contreras, J.I.; Baeza, R.; Segura, M.L.; Lao, M.T. Integral management of irrigation water in intensive horticultural systems of Almería. Sustainability 2017, 9, 2271. [CrossRef]

37. Ait-Mouheb, N.; Bahri, A.; Thayer, B.B.; Benyahia, B.; Bourrié, G.; Cherki, B.; Condom, N.; Declercq, R.; Gunes, A.; Héran, M.; et al. The reuse of reclaimed water for irrigation around the Mediterranean Rim: A step towards a more virtuous cycle? Reg. Environ. Chang. 2018. [CrossRef]

38. Yannopoulos, S.; Giannopoulou, I.; Kaiafa-Saropoulou, M. Investigation of the current situation and prospects for the development of rainwater harvesting as a tool to confront water scarcity worldwide. Water 2019, 11, 2168. [CrossRef]

39. Arampatzis, G.; Hatzigiannakis, E.; Panagopoulos, A.; Karyoti, A.; Vrouchakis, I.; Karyotis, T. Water scarcity and inputs of nutrients from irrigation in olive groves of Crete Island, Greece. J. Plant Nutr. 2018, 41, 2232-2240. [CrossRef]

40. Afzaal, H.; Farooque, A.A.; Abbas, F.; Acharya, B.; Esau, T. Precision irrigation strategies for sustainable water budgeting of potato crop in prince Edward Island. Sustainability 2020, 12, 2419. [CrossRef]

41. Manzardo, A.; Mazzi, A.; Loss, A.; Butler, M.; Williamson, A.; Scipioni, A. Lessons learned from the application of different water footprint approaches to compare different food packaging alternatives. J. Clean. Prod. 2016, 112, 4657-4666. [CrossRef]

42. Hess, T.; Aldaya, M.; Fawell, J.; Franceschini, H.; Ober, E.; Schaub, R.; Schulze-Aurich, J. Understanding the impact of crop and food production on the water environment-using sugar as a model. J. Sci. Food Agric. 2014, 94, 2-8. [CrossRef] [PubMed]

43. Pedrero, F.; Grattan, S.R.; Ben-Gal, A.; Vivaldi, G.A. Opportunities for expanding the use of wastewaters for irrigation of olives. Agric. Water Manag. 2020, 241, 106333. [CrossRef]

44. Deh-Haghi, Z.; Bagheri, A.; Fotourehchi, Z.; Damalas, C.A. Farmers' acceptance and willingness to pay for using treated wastewater in crop irrigation: A survey in western Iran. Agric. Water Manag. 2020, 239, 106262. [CrossRef]

45. Mohtar, R.H.; Daher, B. Water, Energy, and Food: The Ultimate Nexus. In Encyclopedia of Agricultural, Food, and Biological Engineering, 2nd ed.; Informa UK Limited: London, UK, 2010.

46. Dimitrijević, A.; Gavrilović, M.; Ivanović, S.; Mileusnić, Z.; Miodragović, R.; Todorović, S. Energy use and economic analysis of fertilizer use in wheat and sugar beet production in Serbia. Energies 2020, 13, 2631. [CrossRef]

47. Kyriakarakos, G.; Balafoutis, A.T.; Bochtis, D. Proposing a paradigm shift in rural electrification investments in Sub-Saharan Africa through Agriculture. Sustainability 2020, 12, 3096. [CrossRef]

48. Oakleaf, J.R.; Kennedy, C.M.; Baruch-Mordo, S.; Gerber, J.S.; West, P.C.; Johnson, J.A.; Kiesecker, J. Mapping global development potential for renewable energy, fossil fuels, mining and agriculture sectors. Sci. Data 2019, 6, 1-17. [CrossRef]

49. Yates, D.; Meldrum, J.; Averyt, K. The influence of future electricity mix alternatives on southwestern US water resources. Environ. Res. Lett. 2013, 8, 045005. [CrossRef]

50. Aroonsrimorakot, S.; Laiphrakpam, M. Application of solar energy technology in agricultural farming for sustainable development: A review article. Int. J. Agric. Technol. 2019. [CrossRef]

51. Rahnama, M.; Kazemi, N.; Godarzi, B.; Taki, M. Geothermal energy for heating and cooling in agricultural greenhouses. Agric. Eng. Int. CIGR J. 2018, 20, 97-107.

52. Fabrizio, E. Energy reduction measures in agricultural greenhouses heating: Envelope, systems and solar energy collection. Energy Build. 2012, 53, 57-63. [CrossRef] 
53. Vlachokostas, C.; Achillas, C.; Agnantiaris, I.; Michailidou, A.V.; Pallas, C.; Feleki, E.; Moussiopoulos, N. Decision support system to implement units of alternative biowaste treatment for producing bioenergy and boosting local bioeconomy. Energies 2020, 13, 2306. [CrossRef]

54. da Silva Romero, C.W.; Berni, M.D.; Figueiredo, G.K.D.A.; Franco, T.T.; Lamparelli, R.A.C. Assessment of agricultural biomass residues to replace fossil fuel and hydroelectric power energy: A spatial approach. Energy Sci. Eng. 2019, 7, 2287-2305. [CrossRef] [PubMed]

55. Rodias, E.; Berruto, R.; Bochtis, D.; Sopegno, A.; Busato, P. Green, yellow, and woody biomass supply-chain management: A review. Energies 2019, 12, 3020. [CrossRef]

56. Allesina, G.; Pedrazzi, S.; Allegretti, F.; Morselli, N.; Puglia, M.; Santunione, G.; Tartarini, P. Gasification of cotton crop residues for combined power and biochar production in Mozambique. Appl. Therm. Eng. 2018, 139, 387-394. [CrossRef]

57. Ruiz, H.A.; Martínez, A.; Vermerris, W. Bioenergy Potential, Energy Crops, and Biofuel Production in Mexico. Bioenergy Res. 2016, 9, 981-984. [CrossRef]

58. Sopegno, A.; Rodias, E.; Bochtis, D.; Busato, P.; Berruto, R.; Boero, V.; Sørensen, C. Model for energy analysis of Miscanthus production and transportation. Energies 2016, 9, 392. [CrossRef]

59. Rodias, E.; Berruto, R.; Bochtis, D.; Busato, P.; Sopegno, A. A computational tool for comparative energy cost analysis of multiple-crop production systems. Energies 2017, 10, 831. [CrossRef]

60. Rodias, E.C.; Lampridi, M.; Sopegno, A.; Berruto, R.; Banias, G.; Bochtis, D.D.; Busato, P. Optimal energy performance on allocating energy crops. Biosyst. Eng. 2019, 181, 11-27. [CrossRef]

61. Paschalidou, A.; Tsatiris, M.; Kitikidou, K. Energy crops for biofuel production or for food?-SWOT analysis (case study: Greece). Renew. Energy 2016, 93, 636-647. [CrossRef]

62. Bochtis, D.; Benos, L.; Lampridi, M.; Marinoudi, V.; Pearson, S.; Sørensen, C.G. Agricultural workforce crisis in light of the COVID-19 pandemic. Sustainability 2020, 12, 8212. [CrossRef]

63. Toop, T.A.; Ward, S.; Oldfield, T.; Hull, M.; Kirby, M.E.; Theodorou, M.K. AgroCycle-Developing a circular economy in agriculture. Energy Procedia 2017, 123, 76-80. [CrossRef]

64. Angelopoulou, T.; Balafoutis, A.; Zalidis, G.; Bochtis, D. From laboratory to proximal sensing spectroscopy for soil organic carbon estimation-A review. Sustainability 2020, 12, 443. [CrossRef]

65. Kizito, S.; Luo, H.; Lu, J.; Bah, H.; Dong, R.; Wu, S. Role of nutrient-enriched biochar as a soil amendment during maize growth: Exploring practical alternatives to recycle agricultural residuals and to reduce chemical fertilizer demand. Sustainability 2019, 11, 3211. [CrossRef]

66. Vaneeckhaute, C.; Styles, D.; Prade, T.; Adams, P.; Thelin, G.; Rodhe, L.; Gunnarsson, I.; D’Hertefeldt, T. Closing nutrient loops through decentralized anaerobic digestion of organic residues in agricultural regions: A multi-dimensional sustainability assessment. Resour. Conserv. Recycl. 2018, 136, 110-117. [CrossRef]

67. Li, R.; Tao, R.; Ling, N.; Chu, G. Chemical, organic and bio-fertilizer management practices effect on soil physicochemical property and antagonistic bacteria abundance of a cotton field: Implications for soil biological quality. Soil Tillage Res. 2017, 167, 30-38. [CrossRef]

68. Savci, S. An Agricultural Pollutant: Chemical Fertilizer. Int. J. Environ. Sci. Dev. 2012, 73-80. [CrossRef]

69. Lee, J. Effect of application methods of organic fertilizer on growth, soil chemical properties and microbial densities in organic bulb onion production. Sci. Hortic. 2010, 124, 299-305. [CrossRef]

70. Htwe, A.Z.; Moh, S.M.; Moe, K.; Yamakawa, T. Biofertilizer production for agronomic application and evaluation of its symbiotic effectiveness in soybeans. Agronomy 2019, 9, 162. [CrossRef]

71. Jefferies, D.; Muñoz, I.; Hodges, J.; King, V.J.; Aldaya, M.; Ercin, A.E.; Milà I Canals, L.; Hoekstra, A.Y. Water footprint and life cycle assessment as approaches to assess potential impacts of products on water consumption. Key learning points from pilot studies on tea and margarine. J. Clean. Prod. 2012, 33, 155-166. [CrossRef]

72. Wang, E.; Attard, S.; Linton, A.; McGlinchey, M.; Xiang, W.; Philippa, B.; Everingham, Y. Development of a closed-loop irrigation system for sugarcane farms using the Internet of Things. Comput. Electron. Agric. 2020, 172, 105376. [CrossRef]

73. Nahar, J.; Liu, S.; Mao, Y.; Liu, J.; Shah, S.L. Closed-Loop Scheduling and Control for Precision Irrigation †. Ind. Eng. Chem. Res. 2019, 58, 11485-11497. [CrossRef]

74. Goap, A.; Sharma, D.; Shukla, A.K.; Rama Krishna, C. An IoT based smart irrigation management system using Machine learning and open source technologies. Comput. Electron. Agric. 2018, 155, 41-49. [CrossRef]

75. Adeyemi, O.; Grove, I.; Peets, S.; Domun, Y.; Norton, T. Dynamic neural network modelling of soil moisture content for predictive irrigation scheduling. Sensors 2018, 18, 3408. [CrossRef] [PubMed]

76. Rodriguez, C.I.; De Ruiz Galarreta, V.A.; Kruse, E.E. Analysis of water footprint of potato production in the pampean region of Argentina. J. Clean. Prod. 2015, 90, 91-96. [CrossRef]

77. Magdich, S.; Rouina, B.B.; Ammar, E. Olive Mill Wastewater Agronomic Valorization by its Spreading in Olive Grove. Waste Biomass Valorization 2020, 11, 1359-1372. [CrossRef]

78. Rosa, D.M.; Sampaio, S.C.; Pereira, P.A.M.; Mauli, M.M.; Reis, R.R. Dos swine wastewater: Impacts on soil, plant, and leachate. Eng. Agric. 2017, 37, 928-939.

79. Hussain, M.I.; Muscolo, A.; Farooq, M.; Ahmad, W. Sustainable use and management of non-conventional water resources for rehabilitation of marginal lands in arid and semiarid environments. Agric. Water Manag. 2019, 221, 462-476. [CrossRef] 
80. Brînzan, O.; Dragoi, M.; Bociort, D.; Tigan, E.; Mateoc-Sîrb, N.; Lungu, M. A market-based economic instrument to better use water in agriculture. Sustainability 2020, 12, 1473. [CrossRef]

81. Allam, A.; Tawfik, A.; Yoshimura, C.; Fleifle, A. Simulation-based optimization framework for reuse of agricultural drainage water in irrigation. J. Environ. Manag. 2016, 172, 82-96. [CrossRef]

82. Ashu, A.; Lee, S.I. Reuse of agriculture drainage water in a mixed land-use watershed. Agronomy 2019, 9, 6. [CrossRef]

83. Lavrnić, S.; Zapater-Pereyra, M.; Mancini, M.L. Water Scarcity and Wastewater Reuse Standards in Southern Europe: Focus on Agriculture. Water. Air. Soil Pollut. 2017, 228, 251. [CrossRef]

84. Papageorgiou, K.; Singh, P.K.; Papageorgiou, E.; Chudasama, H.; Bochtis, D.; Stamoulis, G. Fuzzy cognitive map-based sustainable socio-economic development planning for rural communities. Sustainability 2020, 12, 305. [CrossRef]

85. Tsolakis, N.K.; Keramydas, C.A.; Toka, A.K.; Aidonis, D.A.; Iakovou, E.T. Agrifood supply chain management: A comprehensive hierarchical decision-making framework and a critical taxonomy. Biosyst. Eng. 2014, 120, 47-64. [CrossRef]

86. Aidonis, D.; Folinas, D.; Achillas, C.; Triantafyllou, D.; Malindretos, G. Multi-criteria evaluation of sustainable supply chains in the agrifood sector. Int. J. Sustain. Agric. Manag. Inform. 2015, 1, 106. [CrossRef]

87. Roghanian, E.; Cheraghalipour, A. Addressing a set of meta-heuristics to solve a multi-objective model for closed-loop citrus supply chain considering CO2 emissions. J. Clean. Prod. 2019, 239, 118081. [CrossRef]

88. Hoehn, D.; Margallo, M.; Laso, J.; García-Herrero, I.; Bala, A.; Fullana-i-Palmer, P.; Irabien, A.; Aldaco, R. Energy embedded in food loss management and in the production of uneaten food: Seeking a sustainable pathway. Energies 2019, 12, 767. [CrossRef]

89. Montoro, S.B.; Lucas, J.; Santos, D.F.L.; Costa, M.S.S.M. Anaerobic co-digestion of sweet potato and dairy cattle manure: A technical and economic evaluation for energy and biofertilizer production. J. Clean. Prod. 2019, 226, 1082-1091. [CrossRef]

90. Blades, L.; Morgan, K.; Douglas, R.; Glover, S.; De Rosa, M.; Cromie, T.; Smyth, B. Circular Biogas-Based Economy in a Rural Agricultural Setting. Energy Procedia 2017, 123, 89-96. [CrossRef]

91. Yu, O.Y.; Ferrell, J.; Kim, H.Y.; Houser, J. NEXUS: Integrated sustainable energy for enhancing farm productivity. In Proceedings of the IOP Conference Series: Earth and Environmental Science, Shanghai, China, 21-24 August 2018.

92. Zabaniotou, A.; Rovas, D.; Libutti, A.; Monteleone, M. Boosting circular economy and closing the loop in agriculture: Case study of a small-scale pyrolysis-biochar based system integrated in an olive farm in symbiosis with an olive mill. Environ. Dev. 2015, 14, 22-36. [CrossRef]

93. Muradin, M.; Joachimiak-Lechman, K.; Foltynowicz, Z. Evaluation of eco-efficiency of two alternative agricultural biogas plants. Appl. Sci. 2018, 8, 2083. [CrossRef]

94. Fan, W.; Zhang, P.; Xu, Z.; Wei, H.; Lu, N.; Wang, X.; Weng, B.; Chen, Z.; Wu, F.; Dong, X. Life cycle environmental impact assessment of circular agriculture: A case study in Fuqing, China. Sustainability 2018, 10, 1810. [CrossRef]

95. Jun, H.; Xiang, H. Development of circular economy is a fundamental way to achieve agriculture sustainable development in China. Energy Procedia 2011, 5, 1530-1534. [CrossRef]

96. Hidalgo, D.; Corona, F.; Martín-Marroquín, J.M. Nutrient recycling: From waste to crop. Biomass Convers. Biorefinery 2020, 1-11. [CrossRef]

97. Molina-Moreno, V.; Leyva-Díaz, J.C.; Llorens-Montes, F.J.; Cortés-García, F.J. Design of indicators of circular economy as instruments for the evaluation of sustainability and efficiency in wastewater from pig farming industry. Water 2017, 9, 653. [CrossRef]

98. Tsai, W.T. Regulatory promotion and benefit analysis of biogas-power and biogas-digestate from anaerobic digestion in taiwan's livestock industry. Fermentation 2018, 4, 57. [CrossRef]

99. Rodias, E.C.; Sopegno, A.; Berruto, R.; Bochtis, D.D.; Cavallo, E.; Busato, P. A combined simulation and linear programming method for scheduling organic fertiliser application. Biosyst. Eng. 2019, 178, 233-243. [CrossRef]

100. Morgano, M.T.; Bergfeldt, B.; Leibold, H.; Richter, F.; Stapf, D. Intermediate pyrolysis of agricultural waste: A decentral approach towards circular economy. Chem. Eng. Trans. 2018, 65, 649-654.

101. Balawejder, M.; Matlok, N.; Gorzelany, J.; Pieniazek, M.; Antos, P.; Witek, G.; Szostek, M. Foliar fertilizer based on calcined bones, boron and molybdenum-a study on the development and potential effects on maize grain production. Sustainability 2019, 11, 5287. [CrossRef]

102. Montemayor, E.; Bonmatí, A.; Torrellas, M.; Camps, F.; Ortiz, C.; Domingo, F.; Riau, V.; Antón, A. Environmental accounting of closed-loop maize production scenarios: Manure as fertilizer and inclusion of catch crops. Resour. Conserv. Recycl. 2019, 146, 395-404. [CrossRef]

103. Bechara, E.; Papafilippaki, A.; Doupis, G.; Sofo, A.; Koubouris, G. Nutrient dynamics, soil properties and microbiological aspects in an irrigated olive orchard managed with five different management systems involving soil tillage, cover crops and compost. J. Water Clim. Chang. 2018, 9, 736-747. [CrossRef]

104. Ferreira, I.Q.; Rodrigues, M.Â.; Claro, A.M.; Arrobas, M. Management of Nitrogen-Rich Legume Cover Crops as Mulch in Traditional Olive Orchards. Commun. Soil Sci. Plant Anal. 2015, 46, 1881-1894. [CrossRef]

105. Duque-Acevedo, M.; Belmonte-Ureña, L.J.; Plaza-Úbeda, J.A.; Camacho-Ferre, F. The management of agricultural waste biomass in the framework of circular economy and bioeconomy: An opportunity for greenhouse agriculture in Southeast Spain. Agronomy 2020, 10, 489. [CrossRef]

106. Alobwede, E.; Leake, J.R.; Pandhal, J. Circular economy fertilization: Testing micro and macro algal species as soil improvers and nutrient sources for crop production in greenhouse and field conditions. Geoderma 2019, 334, 113-123. [CrossRef] 
107. Liu, H.; Ou, X.; Yuan, J.; Yan, X. Experience of producing natural gas from corn straw in China. Resour. Conserv. Recycl. 2018, 135, 216-224. [CrossRef]

108. Manniello, C.; Statuto, D.; Di Pasquale, A.; Giuratrabocchetti, G.; Picuno, P. Planning the flows of residual biomass produced by wineries for the preservation of the rural landscape. Sustainability 2020, 12, 847. [CrossRef]

109. Petropoulos, S.; Fernandes, Â.; Stojković, D.; Pereira, C.; Taofiq, O.; Di Gioia, F.; Tzortzakis, N.; Soković, M.; Barros, L.; Ferreira, I.C.F.R. Cotton and cardoon byproducts as potential growing media components for Cichorium spinosum L. commercial cultivation. J. Clean. Prod. 2019, 240, 118254. [CrossRef]

110. Casson Moreno, V.; Iervolino, G.; Tugnoli, A.; Cozzani, V. Techno-economic and environmental sustainability of biomass waste conversion based on thermocatalytic reforming. Waste Manag. 2020, 101, 106-115. [CrossRef]

111. Vaskalis, I.; Skoulou, V.; Stavropoulos, G.; Zabaniotou, A. Towards circular economy solutions for the management of rice processing residues to bioenergy via gasification. Sustainability 2019, 11, 6433. [CrossRef]

112. Kadoglidou, K.; Kalaitzidis, A.; Stavrakoudis, D.; Mygdalia, A.; Katsantonis, D. A novel compost for rice cultivation developed by rice industrial by-products to serve circular economy. Agronomy 2019, 9, 553. [CrossRef]

113. Antoniou, N.; Monlau, F.; Sambusiti, C.; Ficara, E.; Barakat, A.; Zabaniotou, A. Contribution to Circular Economy options of mixed agricultural wastes management: Coupling anaerobic digestion with gasification for enhanced energy and material recovery. J. Clean. Prod. 2019, 209, 505-514. [CrossRef]

114. Zied, D.C.; Pardo-Giménez, A.; de Oliveira, G.A.; Carrasco, J.; Zeraik, M.L. Study of Waste Products as Supplements in the Production and Quality of Pleurotus ostreatus var. Florida. Indian J. Microbiol. 2019, 59, 328-335. [CrossRef] [PubMed]

115. Aziz, S.; Yaseen, L.; Jamal, A.; Farooq, U.; Qureshi, Z.; Tauseef, I.; Haleem, S.K.; Ali, M.I. Fabrication of biochar from organic wastes and its effect on wheat growth and soil microflora. Pol. J. Environ. Stud. 2020, 29, 1069-1076. [CrossRef]

116. Mosquera-Losada, M.R.; Amador-García, A.; Rigueiro-Rodríguez, A.; Ferreiro-Domínguez, N. Circular economy: Using lime stabilized bio-waste based fertilisers to improve soil fertility in acidic grasslands. Catena 2019, 179, 119-128. [CrossRef]

117. Kuisma, M.; Kahiluoto, H. Biotic resource loss beyond food waste: Agriculture leaks worst. Resour. Conserv. Recycl. 2017, 124, 129-140. [CrossRef]

118. Diacono, M.; Persiani, A.; Testani, E.; Montemurro, F.; Ciaccia, C. Recycling agricultural wastes and by-products in organic farming: Biofertilizer production, yield performance and carbon footprint analysis. Sustainability 2019, 11, 3824. [CrossRef]

119. Loh, S.K.; Lai, M.E.; Ngatiman, M. Vegetative growth enhancement of organic fertilizer from anaerobically-treated palm oil mill effluent (POME) supplemented with chicken manure in food-energy-water nexus challenge. Food Bioprod. Process. 2019, 117, 95-104. [CrossRef]

120. Xu, Z.; Fan, W.; Dong, X.; Wang, X.C.; Liu, Y.; Xue, H.; Klemeš, J.J. Analysis of the functional orientation of agricultural systems from the perspective of resource circulation. J. Clean. Prod. 2020, 258, 120642. [CrossRef]

121. Cheong, J.C.; Lee, J.T.E.; Lim, J.W.; Song, S.; Tan, J.K.N.; Chiam, Z.Y.; Yap, K.Y.; Lim, E.Y.; Zhang, J.; Tan, H.T.W.; et al. Closing the food waste loop: Food waste anaerobic digestate as fertilizer for the cultivation of the leafy vegetable, xiao bai cai (Brassica rapa). Sci. Total Environ. 2020, 715, 136789. [CrossRef]

122. Krishnan, R.; Agarwal, R.; Bajada, C.; Arshinder, K. Redesigning a food supply chain for environmental sustainability-An analysis of resource use and recovery. J. Clean. Prod. 2020, 242, 118374. [CrossRef]

123. Zhu, Q.; Jia, R.; Lin, X. Building sustainable circular agriculture in China: Economic viability and entrepreneurship. Manag. Decis. 2019, 57, 1108-1122. [CrossRef] 